\title{
Chromosome Studies in Bignonieae (Bignoniaceae): The First Record of Polyploidy in Anemopaegma
}

\author{
Fabiana Firetti-Leggieri, ${ }^{1,3 *}$, Itayguara Ribeiro da Costa ${ }^{2}$, \\ Lúcia G. Lohmann ${ }^{3}$, João Semir ${ }^{1}$ and Eliana R. Forni-Martins ${ }^{1}$ \\ ${ }^{1}$ Programa de Pós-graduação em Biologia Vegetal, Departamento de Biologia Vegetal, \\ Instituto de Biologia, Universidade Estadual de Campinas, \\ Caixa Postal 6109, CEP 13083-970, Campinas, SP, Brasil \\ ${ }^{2}$ Departamento de Biologia, Centro de Ciências, Universidade Federal do Ceará, \\ Campus do Pici, Bloco 906, CEP 60.455-760, Fortaleza, CE, Brasil \\ ${ }^{3}$ Departamento de Botânica, Instituto de Biociências, Universidade de São Paulo, \\ Rua do Matão 277, CEP 05508-090, São Paulo, SP, Brasil
}

Received August 5, 2010; accepted March 20, 2011

\begin{abstract}
Summary Anemopaegma (Bignonieae, Bignoniaceae) includes 45 species distributed from Mexico to Northeastern Argentina. The genus is monophyletic and well supported by morphological and molecular characters. However, the delimitation of species within Anemopaegma is complex. In this study, we determined chromosome numbers and interphase nuclei structure for 5 shrubby species of Anemopaegma, 3 of which belong to the Anemopaegma arvense species complex. While most shrubby species analyzed were polyploids $(2 n=4 x=80)$, polyploidy was not encountered among the climbing members of the genus. Furthermore, interphase nuclei was shown to vary among species. In particular, A. album was the only species that presented semi-reticulate interphase nuclei, while $A$. glaucum and A. scabriusculum presented areticulate nuclei. Anemopaegma acutifolium and $A$. arvense, on the other hand, presented an interphase nuclei structure that was intermediate between the areticulate and semi-reticulate types. Overall, our findings suggest that ploidy level may have had an important role in the diversification of the Neotropical genus Anemopaegma.
\end{abstract}

Key words Anemopaegma, Chromosome number, Cytotaxonomy, Interphase nuclei, Evolution, Polyploidy.

Bignoniaceae comprises 81 genera and 840 species (Lohmann and Ulloa 2010) of shrubs, trees and climbers, and represents one of the most diverse plant families in South America (Gentry 1974). Species of Bignoniaceae are mainly distributed through tropical rain forests and dry areas (Fischer et al. 2004), representing the second most diverse family of wood plants in seasonal dry forests (Gentry 1988). The family has been traditionally divided into 8 tribes (Gentry 1980): Bignonieae, Crescentieae, Tourrettieae, Eccremocarpeae, Schlegelieae, Tecomeae, Coleeae and Oroxyleae. However, recent phylogenetic studies have indicated that Tecomeae is highly paraphyletic, while Schlegelieae is best treated as a separate family (Spangler and Olmstead 1999, Olmstead et al. 2009). The most recent classification for the group (Olmstead et al. 2009) recognizes 9 main clades: Bignonieae, Catalpeae, Oroxyleae, Tabebuia Alliance Clade, Paleotropical Clade, Delostoma, Tecomeae, Tourrettieae, and Jacarandeae.

Bignonieae, with 360 species and 21 genera, mainly includes tendrillate climbers of Neotropical distribution (Gentry 1976), and represents the largest clade in the family (Lohmann 2006, Lohmann in press). Within Bignonieae, Anemopaegma, with 45 species of shrubs and lianas, is the third largest genus (Lohmann in press). Anemopaegma is distributed through dry and wet

\footnotetext{
* Corresponding author, e-mail: itayguara@ufc.br
} 
forests, savannas and caatingas from Mexico to Brazil and Argentina, and is characterized by cylindrical stems, foliaceous prophylls of the axillary buds, racemose inflorescences, yellow flowers, glandular calyx and stipitate ovary and fruits (Lohmann in press). Despite the clear circumscription of the genus, the delimitation of the species of Anemopaegma is known to be complicated, perhaps due to hybridization (Gentry 1973). In particular, natural hybridization has been documented in representatives of the "Anemopaegma arvense species complex" (FirettiLeggieri 2009). This species complex includes 3 species (A. acutifolium, A. arvense and $A$. glaucum), and several taxonomic varieties (De Candolle 1845, Bureau and Schumman 1896) that are taxonomically complex.

Chromosome data have been useful for the establishment of species limits in several taxonomic groups (Stace 1991, Briggs and Walters 1997). In particular, similar chromosome numbers suggest a close relationship among taxa while different chromosome numbers imply more distant relationships due to the higher levels of reproductive isolation in those taxa. The type of intherphasic nuclei, the proportion of condensed and diffused euchromatin, and the general nuclear structure are also known to represent important taxonomic characters at different taxonomic levels (Guerra 1985). Despite the great potential of chromosome information for taxonomy, chromosome studies in the Bignoniaceae are still scarce and fragmentary (Goldblatt and Gentry 1979). Out of the 860 species of Bignoniaceae (Fischer et al. 2004), only 113 (13.4\%) species had their chromosome numbers counted (Goldblatt and Gentry 1979, Gentry 1980, Goldblatt 1989, Alcorcés de Guerra 2002, Chen et al. 2004).

Here, we studied chromosome numbers in the "Anemopaegma arvense species complex," and in 2 phylogenetically distant species of Anemopaegma in order to evaluate the potential of chromosome numbers as taxonomic characters in this genus.

Materials and methods

\section{Sampling}

Five species of Anemopaegma were sampled: A. acutifolium, A. album, A. arvense, A. glaucum and $A$. scabriusculum. Most of these species belong to the "Anemopaegma arvense species complex" except for $A$. album and $A$. scabriusculum. In addition, 2 populations corresponding to 2 different morphological forms of $A$. acutifolium, A. arvense and A. glaucum were sampled. These populations were here named as follows: A. acutifolium "scandent morph," A. acutifolium "shrubby morph," A. arvense "linear leaflet morph," A. arvense "lanceolated leaflet morph," A. glaucum "pubescent morph," and A. glaucum "glabrous morph." The exact taxa sampled and locations of the sampled populations are presented in Table 1 .

Materials were collected in natural populations of the Brazilian Cerrado and Campo Rupestre vegetation types. During fieldwork, ripe fruits were collected and seeds selected for germination

Table 1. Species of Anemopaegma sampled, followed by collection location and voucher number. Vegetation types: $\mathrm{CERR}=\mathrm{Cerrado} ; \mathrm{CR}=$ Campo rupestre

\begin{tabular}{lll}
\hline \multicolumn{1}{c}{ Species } & \multicolumn{1}{c}{ Location } & \multicolumn{1}{c}{ Collection number } \\
\hline A. acutifolium "shrubby morph" & Minas Gerais, near Uberlândia; CERR & F. Firetti et al. 43 \\
$\begin{array}{l}\text { A. acutifolium "scandent morph" } \\
\text { A. album }\end{array}$ & Distrito Federal, Brasília; CERR & F. Firetti and C.P. Firetti 193 \\
A. arvense "linear leaflet morph" & Bahia, Mucugê, CR & F. Firetti et al. 111 \\
A. arvense "lanceolated leaflet morph" & Distrito Federal, Brasília; CERR & F. Firetti and C.P. Firetti 185 \\
A. glaucum "pubescent morph" & Distrito Federal, Brasília; CERR & F. Firetti and C.P. Firetti 53 \\
A. glaucum "glabrous morph" & São Paulo, Assis; CERR & F. Firetti et al. 27 \\
A. scabriusculum & Distrito Federal, Brasília; CERR & F. Firetti and C. P. Firetti 178 \\
\hline
\end{tabular}


studies. Vouchers of all sampled taxa were deposited in the herbarium UEC (Universidade Estadual de Campinas, UNICAMP).

\section{Chromosome counts and interphase nuclei structure}

To obtain mitotic metaphases, seeds with embryos from all studied individuals were germinated in wet paper in Petri dishes kept between $28-30^{\circ} \mathrm{C}$. Root tips were pre-treated with 2 $\mathrm{mM} 8$-hydroxyquinoline for $24 \mathrm{~h}$, at $8^{\circ} \mathrm{C}$ and fixed in Farmer solution (3 ethanol: 1 acetic acid) until the preparation of slides. Roots were hydrolyzed in $\mathrm{HCl} 5 \mathrm{~N}$ for $20 \mathrm{~min}$, and squashed in a drop of $45 \%$ acetic acid solution. Slides were stained with Giemsa 2\% solution (Guerra 1983), and subsequently examined under light microscopy. Mitotic cells with a good chromosome condensation and spreading were recorded with a photomicroscope. Chromosome numbers were determined through the analysis of at least 10 metaphases per individual. Interphase nuclei were classified following Guerra (1985).

\section{Results}

The species of "Anemopaegma arvense complex" and A. scabriusculum presented $2 n=80$, while $A$. album presented $2 n=40$. In the "Anemopaegma arvense complex", there was constancy in the chromosome number of the different populations (morphotypes) of their 3 species (Table 2).

Anemopaegma glaucum and A. scabriusculum presented areticulate nuclei, while A. album presented a semi-reticulate interphase nuclei. Anemopaegma acutifolium and A. arvense presented interphase nuclei with a structure that was intermediate between the areticulate and semi-reticulate types (Fig. 1, Table 2). The intermediate structure of interphasic nuclei is characterized by a greater condensation of the chromatin content than the areticulate type, and a lower condensation than the semi-reticulate type.

\section{Discussion}

\section{Chromosome counts}

Prior to this study, only 2 species of Anemopaegma had their chromosome numbers studied: $A$. chamberlaynii (Venkatasubban 1944 apud Darlington and Wylie 1961) and A. orbiculatum (Goldblatt and Gentry 1979), both of which presented $2 n=40$. This study contributed with chromosome counts for 5 additional species of Anemopaegma, increasing total chromosome sampling in Anemopaegma to 16\% (7 of 45 species).

Table 2. Chromosome numbers and interphase nuclei types in Anemopaegma. Interphase nuclei: ARET: Areticulate; S-RET: Semi-reticulate; and, INTERM: Intermediate structure between areticulate and semi-reticulate. Habit: S: Shrub, L: Liana

\begin{tabular}{lcccl}
\hline \hline \multicolumn{1}{c}{ Species } & $2 n$ & Interphase nuclei & Habit & Reference \\
\hline A. acutifolium "shrubby morph" & 80 & INTERM & $\mathrm{S}$ & Present study \\
A. acutifolium "scandent morph" & 80 & INTERM & $\mathrm{S}$ & Present study \\
A. album & 40 & S-RET & $\mathrm{S}$ & Present study \\
A. arvense "linear leaflet morph" & 80 & INTERM & $\mathrm{S}$ & Present study \\
A. arvense "lanceolated leaflet morph" & 80 & INTERM & $\mathrm{S}$ & Present study \\
A. chamberlaynii & 40 & Unknown & $\mathrm{L}$ & Venkatasubban 1944 \\
A. glaucum "pubescent morph" & 80 & ARET & $\mathrm{S}$ & Present study \\
A. glaucum "glabrous morph" & 80 & ARET & $\mathrm{S}$ & Present study \\
A. orbiculatum & 40 & Unknown & $\mathrm{L}$ & Goldblatt and Gentry 1979 \\
A. scabriusculum & 80 & ARET & $\mathrm{S}$ & Present study \\
\hline
\end{tabular}




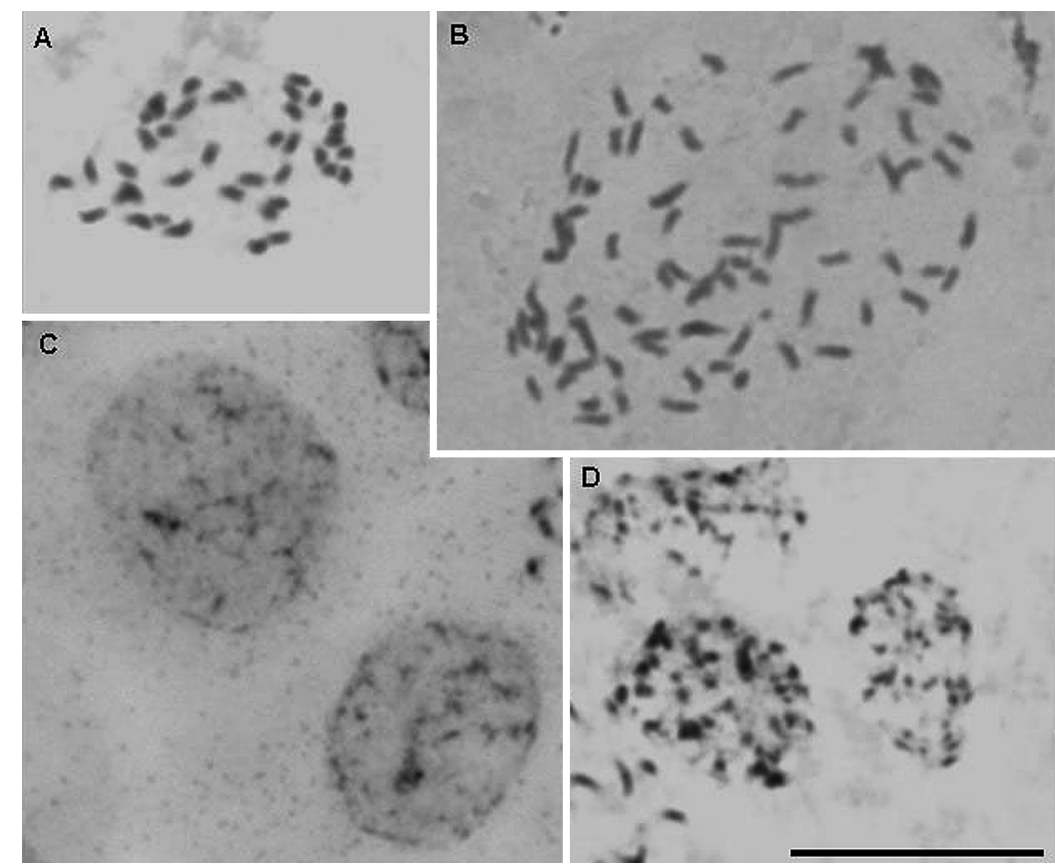

Fig. 1. Chromosomes and interphase nuclei in Anemopaegma. A. A. album, $2 n=40$. B. A. acutifolium "shrubby morph," $2 n=80$. C. Interphase nuclei of $A$. scabriusculum illustrating the areticulate nuclei. D. Interphase nuclei of $A$. album illustrating the semi-reticulate nuclei. Bar: $10 \mu \mathrm{m}$.

The basic chromosome number for all species of Anemopaegma studied was $x=20$, corroborating previous findings by Goldblatt and Gentry (1979) and Raven (1975) for Bignoniaceae. Even though $x=20$ represents the most frequent chromosome number in Bignoniaceae, different chromosome numbers were documented in some clades as Oroxyleae, Tecomeae, Jacarandeae, Delostoma, and in the Tabebuia Alliance. In Oroxyleae, basic chromosome numbers varied between $x=14$ in Oroxylum and $x=15$ in Millingtonia (Goldblatt 1976). In Tecomeae, chromosome numbers different from $x=20$ were recorded in Incarvillea $(x=11$, Chen et al. 2004), Tecoma ( $x=17$, Nakajima 1936 and $x=18$, Goldblatt and Gentry 1979), Tecomaria $(x=17$, Venkatasubban 1944 apud Darlington and Wylie 1961 and $x=18$, Goldblatt and Gentry 1979), Campsis ( $x=19$, Venkatasubban 1944 apud Darlington and Wylie 1961), and Pandorea $(x=19$, Nakajima 1936). In Jacarandeae, chromosome numbers different from $x=20$ were recorded in Jacaranda ( $x=18$, Goldblatt and Gentry 1979, Piazzano 1998), while the chromosome number $x=21$ were recorded in Delostoma (Goldblatt and Gentry 1979). In the Tabebuia Alliance Clade, chromosome numbers different from $x=20$ were recorded in Handroanthus $(x=19$, Alcorcés de Guerra 2002).

\section{Interphase nuclei structure}

Apart from the uniformity of chromosome number within the Anemopaegma arvense species complex $(2 n=80)$, the interphase nuclei structure varied among species from this complex and was useful for species characterization. In particular, Anemopaegma glaucum presented an areticulate interphase nuclei, while $A$. acutifolium and $A$. arvense presented an interphase nuclei structure that was intermediate between the areticulate and semi-reticulate types. Anemopaegma scabriusculum showed the same type of interphase nuclei as A. glaucum (areticulate interphase nuclei), while Anemopaegma album presented a semi-reticulate interphase nuclei (Fig. 1, Table 2). These findings suggest that interphase nuclei structure is useful character for taxonomic delimitation in the plant 
family Bignoniaceae.

Ploidy level

Most species studied, Anemopaegma acutifolium, $A$. arvense, $A$. glaucum and $A$. scabriusculum presented $2 n=80$, except for $A$. album which presented $2 n=40$. These results indicate that 4 out of the 5 species studied (A. acutifolium, A. arvense, A. glaucum, and $A$. scabriusculum) were tetraploids $(2 n=4 x=80)$, representing the first record of polyploidy in Anemopaegma. Even though polyploidy had already been reported for the Bignoniaceae (Piazzano 1998), polyploidy is thought to represent a rare phenomenon in the family (Goldblatt and Gentry 1979). In Bignonieae specifically, tetraploidy was documented in Dolichandra unguis-cati $(2 n=80$, Jullier 1989, Piazzano 1998), while triploidy was reported for Pyrostegia venusta $(2 n=60$, Joshi and Hardas 1956). In the Tabebuia Alliance Clade, tetraploidy was documented in Handroanthus chrysotrichus $(2 n=80$, Piazzano 1998). In this clade, variations in ploidy levels were documented in different populations of Handroanthus chrysotrichus, with diploid and tetraploid cytotypes (Ortolani 2007).

Anemopaegma album and the 2 other species of Anemopaegma previously studied, A. chamberlayni (Venkatasubban 1944 apud Darlington and Wylie 1961) and A. orbiculatum (Goldblatt and Gentry 1979) were shown to be diploid (Table 2). The fact that 4 out of 5 species shrubby species studied are tetraploids, indicates a predominance of polyploidy on shrubby species. Varying chromosome numbers in taxa with different habits was also recorded in Sapindaceae (Lombello and Forni-Martins 1998) and Malpighiaceae (Lombello and Forni-Martins 2003). In Sapindaceae, lianoid taxa were shown to represent more derived lineages and to have evolved from ancestors with a shrubby habit; in this case, a reduction on chromosome numbers followed by an increase in chromatin length was hypothesized on the lianoid taxa. For Malpighiaceae, the lianoid species (subfamily Malpighioideae) were shown to present basic chromosome numbers $x=5$ or $x=10$, while shrubby representatives (Byrsonimoideae) presented $x=6$, the plesiomorphic condition in the family.

Polyploidy promotes hybrid fertility (Grant 1971, Rieseberg 1997, Ramsey and Schemske 1998, Otto and Whitton 2000, Stace 2000, Soltis and Soltis 2000) and is known to present an important role for the hybrid establishment (Stebbins 1971, Rieseberg 1997). Specifically in Anemopaegma, hybridization had already been hypothesized based on observations of individuals with intermediate morphologies (Gentry 1973). In the case of the polyploid species from the Anemopaegma arvense species complex, it is possible that successive hybridization events may have occurred between parental diploids with $2 n=40$. Hand pollination inter-specific events among sympatric species indicate that species from this complex are indeed inter-fertile (Firetti-Leggieri 2009). In natural conditions, gene flow among species of this complex is possible due to their shared floral phenology, pollination strategy, and distribution (Firetti-Leggieri 2009). In sympatric populations of $A$. arvense and $A$. glaucum, hybrid zones containing individuals with intermediate morphology have been observed (Firetti-Leggieri 2009), corroborating the hypothesis of a polyploid or hybrid origin of species in this complex.

\section{Acknowledgements}

The authors are grateful to CNPq (Conselho Nacional de Desenvolvimento Tecnológico) for Ph.D. fellowships to F. Firetti-Leggieri and I. R. Costa, as well as for a research fellowships to E. R. Forni-Martins. 


\section{References}

Alcorcés de Guerra, N. 2002. Cariología de dos especies del gênero Tabebuia Gomes (Bignoniaceae). Revista UDO Agrícola 2: 14-21.

Briggs, D, and Walters, S. M. 1997. Plant variation and evolution. Cambridge University Press, Cambridge.

Bureau, L. E. and Schumann, K. M. 1896. Bignoniaceae. In Flora brasiliensis (C. F. P. Martius \& A. G. Eichler, eds.). F. Fleisher, Lipsiae, v. 8, pars 2, p. 1-451.

Chen, S. T., Zhou, Z. K., Guan, K. Y. and Nakata, M. 2004. Karyomorphology of Incarvillea (Bignoniaceae) and its implications in distribution and taxonomy. Bot. J. Linn. Soc. 144: 113-121.

Darlington C. D, and Wylie A. P. 1961. Chromosome atlas of flowering plants. 2nd edition. 2nd impression. George Allen and Unwin Ltd., London.

Candolle, A. 1845. Bignoniaceae. In: De Candolle, A. (ed.). Prodomus Systematis Naturalis regnis vegetabilis. Paris, Treuttel et Wurtz. Paris. pp. 187-192.

Firetti-Leggieri, F. 2009. Biossistemática das espécies do complexo Anemopaegma arvense (Vell.) Stellf. ex de Souza: aspectos anatômicos, citológicos, moleculares, morfológicos e reprodutivos. Ph D Thesis. Universidade Estadual de Campinas.

Fischer, E, Theisen, I, and Lohmann, L. G. 2004. Bignoniaceae. In: Kadereit, J. W. and Kubitzki, K. (eds.). The families and genera of vascular plants. 1 ed., vol. 7. Springer, Berlin, pp. 9-98.

Gentry, A. H. 1973. Flora do Panamá: Bignoniaceae. Ann. Mo. Bot. Gard. 60: 781-977.

- 1974. Coevolutionary patterns in Central American Bignoniaceae. Ann. Mo. Bot. Gard. 61: 728-759.

- 1976. Bignoniaceae of southern Central America: Distribution and ecological specificity. Biotropica 8: 117-131.

— 1980. Bignoniaceae, Part 1—Tribes Crescentieae and Tourrettieae. Flora Neotropica Monograph. 25: 1-130.

- 1988. Changes in plant community diversity and floristic composition environmental and geographical gradients. Ann. Mo. Bot. Gard. 75: 1-34.

Goldblatt, P. 1976. New and noteworthy chromosome records in the angiosperms. Ann. Mo. Bot. Gard. 63: 889-895.

- 1989. Miscellaneous Chromosome Counts in Asteraceae, Bignoniaceae, Proteaceae and Fabaceae. Ann. Mo. Bot. Gard. 76: 1186-1188.

— and Gentry, A. H. 1979. Cytology of Bignoniaceae. Bot. Not. 132: 475-482.

Grant, V. 1971. Plant Speciation. Columbia University Press, New York and London.

Guerra, M. S. 1983. O uso de Giemsa em citogenética vegetal—comparação entre a coloração simples e o bandamento. Ciênc. Cult. 35: 190-193.

— 1985. Estrutura e diversificação dos núcleos interfásicos em plantas. In: Aguiar-Perecin, M. L. R, Martins, P. S, and Bandel, G. (eds.). Tópicos de Citogenética e Evolução de Plantas. Sociedade Brasileira de Genética, Ribeirão Preto. pp. 137-153.

Joshi, A. B, and Hardas, M. W. 1956. Ploidy in two Bignoniaceous garden climbers. Indian J. Genet. Plant Breed. 16: 57-59.

Jullier, S. 1989. Cromosomas mitóticos de Dolichandra cynanchoides y Macfadyena unguis-cati (Bignoniaceae). Kurtziana 20: 215-217.

Lohmann, L. G. 2006. Untangling the Phylogeny of Neotropical Lianas (Bignonieae, Bignoniaceae). Am. J. Bot. 93: 304-318

— in press. A new generic classification for Bignonieae (Bignoniaceae). Ann. Mo. Bot. Gard.

— and Ulloa, C. U. 2010. Bignoniaceae. In: iPlants prototype Checklist. Disponível em: www.iplants.org (acessado 19 de julho de 2010).

Lombello, R, and Forni-Martins, E. R. 1998. Chromosomal studies and evolution in Sapindaceae. Caryologia 51: 81-93.

- and - 2003. Malpighiaceae: correlations between habit, fruit type and basic chromosome number. Acta Bot. Bras. 17: $171-178$.

Nakajima, G. 1936. Chromosome numbers in some crop and wild Angiosperms. Jpn. J. Genet. 12: 211-218.

Olmstead, R. G, Zjhra, M. L, Lohmann, L. G, Grose, S. O, and Eckert, A. J. 2009. A molecular phylogeny of Bignoniaceae. Am. J. Bot. 96: 1731-1743.

Ortolani, F. A. 2007. Morfo-anatomia, citogenética e palinologia em espécies de ipê (Bignoniaceae). PhD Thesis. Faculdade de Ciências Agrárias e Veterinárias. UNESP. Jaboticabal, SP.

Otto, S. P. and Whitton, J. 2000. Polyploidy: incidence and evolution. Annu. Rev. Genet. 34: 401-437.

Piazzano, M. 1998. Números cromosómicos em Bignoniaceae de Argentina. Kurtziana 26: 179-219.

Ramsey, J, and Schemske, D. W. 1998. Pathways, mechanisms, and rates of polyploid formation in flowering plants. Annu. Rev. Ecol. Syst. 29: 467-501.

Raven, P. H. 1975. The bases of angiosperm phylogeny: cytology. Ann. Mo. Bot. Gard. 62: 724-764.

Rieseberg, L. H. 1997. Hybrid origins of plant species. Annu. Rev. Ecol. Syst. 28: 359-389.

Soltis, P. S., and Soltis, D. E. 2000. The role of genetic and genomic attributes in the success of polyploids. PNAS U.S.A. 
97: 7051-7057.

Spangler, R. E, and Olmstead, R. G. 1999. Phylogenetic analysis of Bignoniaceae based on the cpDNA gene sequences rbcL and ndhF. Ann. Mo. Bot. Gard. 86: 33-46.

Stace, C. A. 1991. Plant taxonomy and biosystematics. 2nd ed. Cambridge University Press, Cambridge.

- 2000. Cytology and cytogenetics as a fundamental taxonomic resource for the 20th and 21th centuries. Taxon 49: 451-477.

Stebbins, G. L. 1971. Chromosome variation in higher plants. Edward Arnold, London. 